\title{
STRATEGIES OF TRANSLATING QUR'ANIC CULTURAL TERMS
}

\author{
Ghada Rajeh Ayyad ${ }^{1}$ \\ School of Languages, Literacies and Translation, \\ Universiti Sains Malaysia, 11800 Universiti Sains Malaysia, Penang, Malaysia. \\ (Email: ayyad.ghada@gmail.com) \\ Tengku Sepora Tengku Mahadi \\ Universiti Sains Malaysia, 11800 Universiti Sains Malaysia, Penang, Malaysia. \\ (Email: tsepora@usm.my)
}

Received date: 03-09-2019

Revised date: $22-09-2019$

Accepted date: 23-09-2019

Published date: 23-09-2019

To cite this document: Ayyad, G. R., \& Mahadi, T. S. T. (2019). Strategies of Translating Qur'anic Cultural Terms. International Journal of Humanities, Philosophy and Language, 2(7), 139-147.

DOI: $10.35631 / \mathrm{ijhpl} .270012$

Abstract: The translation of cultural terms is considered one of the most difficult challenges a translator may face. This is due to the fact that such terms have specific meanings in the source language and culture which do not exists in others. In fact, translating cultural terms become more complicated when dealing with religious texts due to the sensitivity of these texts. One of the most challenging texts for translators is the Noble Qur'an. The translator of Qur'anic cultural terms is required to be very accurate as the mistranslation of such terms may lead to a complete distortion of the meaning. To help in producing equivalent translation for cultural terms, two translation strategies were suggested by Venuti in 1995. These strategies are domestication and foreignization. The present study investigates the use of both strategies by the translators of the Noble Qur'an in translating cultural terms. Also, it tries to find out which strategy can be applied to achieve equivalence in translation.

Keywords: Religious Translation, Cultural Terms, Domestication and Foreignization, The Noble Qur'an

\section{Introduction}

Translation theorists and scholars have introduced new strategies of translation to overcome translation problems. Some of these problems have aroused due to the differences between two 
languages. Such differences can be cultural, religious, political, geographical, etc. The difference in culture between two languages has posed a major problem in the translation field. Translation of culture has become the focus of attention of translation theorists. Nida \& Taber (1982, p.199) defined the translation of culture as "translation in which the content of the message is changed to conform to the receptor culture in some way, and/or in which information is introduced which is not linguistically implicit in the original". Some believe that translating culture cannot be faithful as it is almost impossible for a translator to find an exact equivalent word for the source culture one. In addition to be bilingual, translating a cultural term from one language into another requires the translator to be bicultural. $\mathrm{He} /$ she should have enough knowledge about both the target and the source language cultures. However, the problem of translating such terms remains unsolved. To help in overcoming such an obstacle, strategies of translating cultural terms need to be applied in order to "reflect an approximation of those terms or provide acceptable compensation for an inescapable cultural loss" (Al-Azzam et al. $(2015$, p.1).

Two strategies of translation were developed by Venuti to translate cultural terms. These strategies are domestication and foreignization. Domestication means to replace the source language culture with the target language culture, while foreignization means to maintain the source culture and transfer it to the target culture (Yang, 2010, p.77). These two strategies are believed to be the solution for the problem of translating cultural terms. Yet, there is a difference in opinions between translation theorists regarding these strategies. Some support the use of domestication strategy while others opt for using the foreignization. Translating cultural terms can be more challenging when dealing with religious text. As it is known, religious texts such as the Noble Qur'an are sensitive and the translator should be very careful when translating such texts. The Noble Qur'an is completely different from any other text. Some scholars believe that translating such a text is an impossible mission. According to Beaugrande (2003, p.8), the most challenging book for translators is the Noble Qur'an. Translators of the Noble Qur'an tend to use Venuti's strategies to translate cultural terms equivalently. This study aims to investigate the use of domestication and foreignization strategies to translate cultural terms in the Noble Qur'an.

\section{Literature Review}

\section{Culture, Language and Translation}

Culture refers to the way of life of people that includes customs, traditions, beliefs, folklore and habits. Newmark (1988, p.222) defines culture as "the way of life and its manifestations that are peculiar to a community that uses a particular language as its mean of expression". There is no doubt that culture has a significant influence on language. In fact, they depend on each other. Language can be considered as a part of culture. In Wang's (2014) opinion, if a translator wants to understand a language, he/she should have knowledge about its culture and vice versa. Thus, learning a language includes learning its culture. The influence of culture on language creates an obstacle to translators. Shuttleworth \& Cowie (1997, p.35), defines translation of culture as "a term used informally to refer to types of translation which function as a tool for cross-cultural or anthropological research, or indeed to any translation which is sensitive to cultural as well as linguistic factors".

Cultural terms are defined as "those actualized items whose function and connotation in a source text involve a translation problem in their transference to a target text, whenever this problem is 
a product of the nonexistence of the referred item or of its different intertextual status in the cultural system of the readers of the target text" (Aixelá, 1996, p. 58). The importance of accurate translation of culture-specific-terms can be seen in the translation of religious texts such as the Noble Qur'an where mistranslating any of the cultural terms can cause a total distortion of meaning. One of the problems that the Noble Qur'an translators face is the cultural terms. AbdulRaof (2001, p.149) defines cultural terms in the Noble Qur' an as 'culture-bound Qur'anic lexical items which are semantic voids and whose meaning needs to be further explicated in commentaries or footnotes".

\section{Domestication and Foreignization Strategies}

In his book, The Translator's Invisibility (1995), Venuti introduced the domestication and foreignization strategies for the first time. Those strategies are suggested to be used for translating cultural terms. The foreignization strategy is source-culture oriented while the domestication strategy is target-culture-oriented. Shuttleworth \& Cowie (1997, p.44) defines domestication as a strategy for translating culture-specific-terms through using a clear and fluent style to remove the strangeness of the source text for the target text readers. As for the foreignization strategy, they defined it as "a term used by Venuti (1995) to designate the type of translation in which a TT is produced which deliberately breaks target conventions by retaining something of the foreignness of the original" (p.59). In general, domestication is replacing the culture of the SL with the culture of the TL, while foreignization is to preserve the culture of the SL in the culture of the TL. (Yang, 2010, p.77).

Both strategies are widely used by translators in translating cultural terms. However, some theorists prefer the domestication strategy while others prefer the foreignization. Venuti (1995, p.15) argues that domestication has a negative connotation and calls it "aggressively monolingual, unreceptive to the foreign". He added that domestication "provides readers with the narcissistic experience of recognizing their own culture in a cultural other" (p.15). Nida (1964, p.159) has a different opinion. He supports the use of domestication as he developed the concept of dynamic equivalence which is not different form this strategy. He says that "A translation of dynamic equivalence aims at complete naturalness of term and tries to relate the receptor to modes of behavior relevant within the context of his own culture". As for Zhu (2002), he agrees with Nida's opinion. He sees that the TT readers should feel the similarities between both cultures. He argues that using the domestication strategy will make the target text smoother and clearer to the readers.

Shuttleworth \& Cowie (1997, p.59) believe that using the foreignization strategy "would entail not only a freedom from absolute obedience to target linguistic and textual constraints, but also where appropriate the selection of a non-fluent, opaque style and the deliberate inclusion of SL realia or TL archaisms". Venuti (1995, p.20) thinks that foreignization has a significant role in transferring and maintaining the source text culture and linguistic differences in the target text, so the target text readers can have a sense of being abroad and provide them with an "alien reading experience". Far from domestication, foreignization gives the TT readers the chance to learn about the foreign culture and its linguistic differences. As a matter of fact, foreignization becomes "highly desirable today, a strategic cultural intervention in the current state of world affairs," (p.20). Venuti (1995, p.20) supported the foreignization strategy as he believes that it is "a form of resistance against ethnocentrism and racism, cultural narcissism and imperialism, in 
the interests of democratic geopolitical relations". He added that foreignization supports the equality between cultures.

In general, the two strategies can be used to reach equivalence in translation. On one hand, the domestication strategy aims to remove the linguistic and cultural barriers between the source and target languages. On the other hand, the foreignization strategy preserves the source culture and transfers it to the target culture readers. According to Wang (2013 p.175), "both strategies are deeply rooted in specific social and cultural circumstances where the choice of domestication and foreignization is not only made by the translator, but more importantly, by the specific social situations and cultural traditions".

\section{Objectives of the Study}

This study aims to study Venuti's domestication and foreignization strategies used by the translators of the Noble Qur'an to translate the cultural terms into English. It also attempts to find out which strategy conveyed the meaning equivalently.

\section{Corpora of the Study}

The corpora of this study are the Noble Qur'an in Arabic as the source text and three selected English translations as the target text. The first target text is The Meaning of the Glorious Qur'an by Marmaduke Pickthall (1930), the second target text is The Message of the Qur'an by Muhammad Asad (1980) and the third target text is Translation of the Meanings of the Noble Qur'an in the English Language by Hilali and Khan (1996).

\section{Methodology}

A descriptive qualitative analysis is conducted to study the corpora of this study. The study analyzes the translation of cultural terms in the Noble Qur'an from Arabic into English. The researcher selects 10 examples from the Noble Qur'an. These examples are studied along with their three selected translations in English. The meaning of the selected terms is explained based on the "Dictionary of Islamic Words and Expressions" by Saleh (2011). This dictionary is unique as it provides the meanings of all Islamic and cultural words and expressions in the Noble Qur'an. The researcher finds out if cultural terms are domesticated or foreignized and which strategy succeeded in transferring the intended meaning.

\section{Data Analysis}

In this section, 10 examples of Qur'anic cultural terms are analyzed. Each example is listed in a table along with its transliteration and its three English translations.

Table 1: Translation of Qur'anic Cultural Terms. Example 1.

\begin{tabular}{|l|l|l|l|l|}
\hline Term & Transliteration & $1^{\text {st }}$ translation & $2^{\text {nd }}$ translation & $3^{\text {rd }}$ translation \\
\hline روح القدأ & rūhi Al-Qudus & $\begin{array}{l}\text { Rûh-ul-Qudus [Jibrael } \\
\text { (Gabriel). }\end{array}$ & Holy inspiration & $\begin{array}{l}\text { Ruh-ul-Qudus } \\
{[\text { Jibrael }} \\
\text { (Gabriel)]. }\end{array}$ \\
\hline
\end{tabular}

The first translator and the third translators decided to use the foreignization strategy to translate this term. They used two translation procedures. The firs procedure is the transliteration "Rûh-ul- 
Qudus" and the second procedure is the addition as they added the name of the angel "Gabriel". For non-Muslims, Gabriel is unknown. The translators should have added that Gabriel is the Archangel. The second translator decided to use the domestication strategy. He found an equivalent for this term in English language which is "the holy inspiration". Although this translation may seem natural in the target language, it did not convey the intended meaning. The holy inspiration in Islam is different from the one in Christianity. Thus, the domestication strategy failed to transfer the accurate meaning in this case. Therefore, the choice of the first and third translators to foreignize this term is better than the second translator who chose to domesticate it.

Table 2: Translation of Qur'anic Cultural Terms. Example 2.

\begin{tabular}{|l|l|l|l|l|}
\hline Term & Transliteration & $1^{\text {st }}$ Translation & $2^{\text {nd }}$ Translation & $3^{\text {rd }}$ Translation \\
\hline الحج & Hajj & Pilgrimage & $\begin{array}{l}\text { Pilgrimage } \\
\text { +footnote }\end{array}$ & $\begin{array}{l}\text { Hajj (i.e. the pilgrimage } \\
\text { to Makkah) }\end{array}$ \\
\hline
\end{tabular}

The term 'Hajj' means pilgrimage to Mecca. Every able Muslim should perform Hajj once in his/her life in a specific month (Dhul Hijjah) and in a certain manner. (Saleh, 2011). The first translator chose to domesticate this term and found an equivalent term in English (pilgrimage). However, the pilgrimage in Islam is different from the pilgrimage in Christianity and in other religions. In Islam, the pilgrimage takes place in Mecca and the Muslim pilgrims perform special rituals. In other religions such as Christianity, the pilgrimage takes place in Jerusalem and the Christian pilgrims perform certain rituals that is completely different from the Muslims ones. Accordingly, the meaning was not conveyed correctly in this translation and resulted in misunderstanding of the term. The second translator translated the term into 'pilgrimage' and added a footnote explaining the meaning of pilgrimage in Islam. He mentioned the time, place and rituals of Muslim pilgrimage. His translation fully conveyed the intended meaning. The third translator followed the foreignization strategy in his translation. He transliterated the term and added an explanation showing that 'Hajj' means pilgrimage to Makkah. In this case, the meaning is conveyed properly.

Table 3: Translation of Qur'anic Cultural Terms. Example 3.

\begin{tabular}{|l|l|l|l|l|}
\hline Term & Transliteration & $1^{\text {st }}$ Translation & $2^{\text {nd }}$ Translation & $3^{\text {rd }}$ Translation \\
\hline صيام & Saum & Fast & $\begin{array}{l}\text { Fasting } \\
+ \text { footnote }\end{array}$ & $\begin{array}{l}\text { Saum (the fasting) } \\
+ \text { footnote }\end{array}$ \\
\hline
\end{tabular}

Fasting in Islam means to refrain from eating, drinking and sexual intercourse from pre-dawn time until sunset (Saleh, 2011). The first translator followed the domestication strategy and translated it into 'fast' which seems natural in English. Yet, fasting in Islam is very different from fasting in Christianity. Therefore, he failed in transferring the meaning. The second translator conveyed the meaning correctly as he replaced the term with an equivalent one and added a footnote in which he explained the time and way of fasting. As for the third translator, he decided to foreignize the term. He transliterated it, added an equivalent in English between brackets and a footnote that shows the meaning of fasting in Islam. This translation is the best as it transferred both the meaning and the culture to the target text. 
Table 4: Translation of Qur'anic Cultural Terms. Example 4.

\begin{tabular}{|l|l|l|l|l|}
\hline Term & Transliteration & $1^{\text {st }}$ Translation & $2^{\text {nd }}$ Translation & $3^{\text {rd }}$ Translation \\
\hline الصالاة & As-Salaat & Worship & Prayer & As-Salat + footnote \\
\hline
\end{tabular}

The first and the second translators used the domestication strategy and the third one used the foreignization. The meaning was not conveyed in the first and second translations as the worship and prayer in Islam is different from the ones in other religions. The third one conveyed the meaning as he transliterated the term and add a footnote to explain what prayer in Islam is.

Table 5: Translation of Qur'anic Cultural Terms. Example 5.

\begin{tabular}{|l|l|l|l|l|}
\hline Term & Transliteration & $1^{\text {st }}$ Translation & $2^{\text {nd }}$ Translation & $3^{\text {rd }}$ Translation \\
\hline الزكاة & Az-Zakaata & $\begin{array}{l}\text { Pay the poor- } \\
\text { due + footnote }\end{array}$ & $\begin{array}{l}\text { Charity }+ \\
\text { footnote }\end{array}$ & Zakat \\
\hline
\end{tabular}

The first and second translators chose to domesticate the term. They found an equivalent term in English and added a footnote to explain the intended meaning. The type of charity mentioned here is different from any other type. It has specific time and rules. Yet, adding a footnote explaining this made the translation successful. As for the third translator, he foreignized the term. He only transliterated it. Unfortunately, he did not transfer the meaning and the target text term seemed strange in the target language without an explanation of the meaning.

Table 6: Translation of Qur'anic Cultural Terms. Example 6.

\begin{tabular}{|c|l|l|l|l|}
\hline Term & Transliteration & $1^{\text {st }}$ Translation & $2^{\text {nd }}$ Translation & $3^{\text {rd }}$ Translation \\
\hline تهجد & Tahajjad & Awake & $\begin{array}{l}\text { Pray during part } \\
\text { of the night }+ \\
\text { footnote }\end{array}$ & $\begin{array}{l}\text { Offer the Salat (prayer) } \\
\text { with it (i.e. recite the } \\
\text { Qur'an in the prayer) as an } \\
\text { additional prayer (Tahajjud } \\
\text { optional prayer). }\end{array}$ \\
\hline
\end{tabular}

The first and second translators decided to domesticate the term. However, the second translator conveyed the meaning while the first one failed to do so. The first translator translated the term into 'awake at night' which is different from the intended meaning. The second one defined the term and added a footnote to farther explain the meaning. The third one applied the foreignization strategy as he transliterated the term and explained the meaning. His translation is the best.

Table 7: Translation of Qur'anic Cultural Terms. Example 7.

\begin{tabular}{|l|l|l|l|l|}
\hline Term & Transliteration & $1^{\text {st }}$ Translation & $2^{\text {nd }}$ Translation & $3^{\text {rd }}$ Translation \\
\hline ابي لهب & Abī Lahab & Abu Lahab & $\begin{array}{l}\text { Of him of the glowing } \\
\text { countennce }\end{array}$ & Abu Lahab \\
\hline
\end{tabular}


The foreignization strategy is obvious in the first and third translations. The translators transliterated the term which is a proper name. The second translator domesticated the term. He deleted the name and replace it with a description of this person because 'Abu Lahab' means the father of flame (literally).

Table 8: Translation of Qur'anic Cultural Terms. Example 8.

\begin{tabular}{|l|l|l|l|l|}
\hline Term & Transliteration & $1^{\text {st }}$ Translation & $2^{\text {nd }}$ Translation & $3^{\text {rd }}$ Translation \\
\hline جزية & Jizyata & Tribute & Exemption tax & Jizya + footnote \\
\hline
\end{tabular}

In the first and second translations the translators used the domestication strategy by replacing the term with an equivalent one in English. Unfortunately, the terms tribute and exemption tax do not convey the exact meaning. The third translator used the foreignization strategy and transferred the meaning correctly. He transliterated the term and defined it in a footnote.

Table 9: Translation of Qur'anic Cultural Terms. Example 9.

\begin{tabular}{|l|l|l|l|l|}
\hline Term & Transliteration & $1^{\text {st }}$ Translation & $2^{\text {nd }}$ Translation & $3^{\text {rd }}$ Translation \\
\hline ج & Junub & Polluted & $\begin{array}{l}\text { A state } \\
\text { requiring total } \\
\text { ablution }\end{array}$ & $\begin{array}{l}\text { In a state of Janaba (in a state } \\
\text { of sexual impurity and have } \\
\text { not yet taken a bath). }\end{array}$ \\
\hline
\end{tabular}

In the first translation, the translator tried to find an equivalent term, but he failed. The meaning of the ST is completely different form the meaning of the TT. Thus, the domestication strategy failed. The domestication strategy was used in the second translation as well. The translator used the definition procedure to translate the term. Yet, the meaning was not conveyed in full. In the third translation, the term was foreignized and the meaning was fully conveyed. The translator transliterated the term and explained it.

Table 10: Translation of Qur'anic Cultural Terms. Example 10.

\begin{tabular}{|l|l|l|l|l|}
\hline Term & Transliteration & $1^{\text {st }}$ Translation & $\begin{array}{l}2^{\text {nd }} \\
\text { Translation }\end{array}$ & $3^{\text {rd }}$ Translation \\
\hline ظهار & Zihar & $\begin{array}{l}\text { Declare to be } \\
\text { your mothers } \\
\text { +footnote }\end{array}$ & $\begin{array}{l}\text { As unlawful } \\
\text { to you as your } \\
\text { mothers' } \\
\text { bodies } \\
\text { + footnote }\end{array}$ & $\begin{array}{l}\text { Declare to be like your mothers' } \\
\text { backs (Az-Zihar is the saying of } \\
\text { a husband to his wife, “you are } \\
\text { to me like the back of my } \\
\text { mother", i.e. you are unlawful } \\
\text { for me to approach. }\end{array}$ \\
\hline
\end{tabular}

The domestication strategy is used in the first and second translations. Both translations conveyed the meaning. In the third translation, the translator used the foreignization strategy and conveyed the meaning as well. 


\section{Conclusion}

As noticed from the above examples, the translators tended to use both strategies in an attempt to reach equivalence in translation. Some chose to use the foreignization strategy more often than the domestication one because they were not able to find an equivalent term in the TL that has the same meaning. In contrast, others preferred to use the domestication strategy in most of their translations in order to produce a natural and clear translation without paying attention to the difference in meaning. This led to a complete distortion of the meaning.

In general, both strategies can be used in translating cultural terms. However, the foreignization strategy appeared to be better in conveying the meaning from the domestication strategy. The domestication strategy can be used in only few cases as it is difficult to find an equivalent for cultural terms. As seen from the examples, the domestication strategy succeeded in conveying the meaning in some cases, conveyed the meaning but not in full in other cases and sometimes failed to transfer the meaning. In contrast, the foreignization strategy succeeded in conveying the meaning in almost all examples. It preserved the source culture and transferred it to the target culture which gave the readers the opportunity to learn new words from other cultures. Unlike the domesticated terms, the meaning of the foreignized terms was clearly explained and transferred by using footnotes. Although the equivalent terms used in the domestication strategy seems equivalent and natural, their meanings in the target language are completely different from their meanings in the source culture. As a result, the translators are advised to use the foreignization strategy in translating cultural words unless they were able to find an equivalent term in the TL that conveys the exact meaning.

\section{References}

Abdul-Raof, H. (2001). Qur'an Translation: Discourse, Texture and Exegesis. Richmond: Curzon Press.

Aixela, J. F. (1996). “Culture-specific items in translation”. In Alvarez, R \& Vidal, C. (1996).

Translation, power, subversion. Cleveland/Bristol/Adelaide: Multilingual Matters. Ltd.

Al-Azzam, B., Al Ahaydib, M. \& Al Huqail, E. (2015). Cultural Problems in the

Translation of the Qur'an. International Journal of Applied Linguistics and

Translation. 1(2): 28-34

Asad, M. (1980). The Message of the Qur'an. Gibraltar: Dar Al-Andalus.

Beaugrande, R. (2003). On the Concept of Sensitive Translation. Offshoot: A Journal of Translation and Comparative Studies 5(1): 1-14.

Hilali, M. \& Khan, M. (1996). Translation of the Meanings of the Noble Qur'an in the English Language. KSA: King Fahd Complex for the Printing of the Holy Qur'an.

Newmark, P. (1988). A Textbook of Translation. New York: Prentice Hall.

Nida, E. (1964). Toward a Science of Translating. Leiden: E.J. Brill.

Nida, E, \& Taber, C. (1982). The Theory and Practice of Translation. Leiden: E. J. Brill.

Pickthall, M. (1930). The Meaning of the Glorious Qur'an: An Explanatory Translation. London: George Allen \& Unwin Ltd.

Saleh, M. I. (2001). A dictionary of Islamic words and Expressions. Riyadh: Al-Muhtada alIslami.

Shuttleworth, M. and Cowie, M. (1997). Dictionary of Translation Studies. Manchester: St. Jerome. 
Venuti, L. (1995). The Translator's Invisibility: A History of Translation. London: Routledge.

Wang, L. (2013). A Survey on Domestication and Foreignization Theories in Translation. Theory and Practice in Language Studies. 3 (1), 175-179.

Wang, F. (2014). An Approach to Domestication and Foreignization from the Angle of Cultural Factors Translation. Theory and Practice in Language Studies. 4 (11), 2423-2427.

Yang, W. (2010). Brief Study on Domestication and Foreignization in Translation. Journal of Language Teaching and Research. 1 (1), 77-80.

Zhu, J. (2002). Domestication and Foreignization: Shift of Researching Point. Journal of PLA University of Foreign Languages.2, 78-82. 